\title{
Supplemental concentrates with four levels of crude protein for grazing Dairy Cows'
}

\author{
Paul F. Randel
}

\begin{abstract}
Four treatments $\left(T_{1}\right.$ through $\left.T_{4}\right)$, based on pelleted concentrates varying in as fed crude protein (CP) contents $(10.8,12.2,13.4$, and $15.3 \%$, respectively), but theoretically isocaloric (1.67-1.70 Mcal net energy/kg), were compared for efficacy as pasture supplements. Eighteen multiparous cows began the experiment individually not later than 8 weeks postpartum. Five were assigned to $T_{1}$ and $T_{3}$ and four to $T_{2}$ and $T_{4}$. Daily concentrate allowances were according to milk production, but $4.5 \mathrm{~kg}$ was set as the arbitrary minimum. Nocturnal rotational grazing was in 120.5 -ha paddocks of little fertilized, heterogeneous, gramineous swards, which flucfuated in quality from adequate to marginal during $11 \frac{1 / 2}{2}$ months of experimentation. Cows assigned to the four treatments in order produced $21.3 \pm 3.0,22.5 \pm 4.4,20.3 \pm 2.5$, and $20.4 \pm 4.5 \mathrm{~kg}$ of milk daily during the 5 days before commencing the experiment, and $14.4 \pm 1.2$, $16.8 \pm 3.9,15.2 \pm 2.4$ and $14.2 \pm 2.4 \mathrm{~kg}$ during the 32 weeks of experimentation. Although treatments did not differ significantly $(P>.05)$ over-all, $T_{1}$ dropped in daily production by $2.7 \mathrm{~kg}$ during the initial 4-week interval and persistency decreased in high-producing cows; $T_{2}$ also caused a large early decline in production, but superior persistency thereafter. Mean milk fat percentages were $2.78 \pm .49,2.68 \pm .44,2.88 \pm .33$, and $3.17 \pm .37 \mathrm{for} T_{1}$ through $T_{4}$. Early depression of milk fat was probably due to high concentrate and inadequate fiber intakes. Concentrate intake ranged from $5.82 \mathrm{~kg}$ in $\mathrm{T}_{4}$ to $7.10 \mathrm{~kg}$ in $T_{2}$ over 32 weeks; milk/concentrate ratio ranged from 2.33 in $T_{3}$ to 2.45 in $T_{4}$. Only in $T_{1}$ was appreciable liveweight $(20 \mathrm{~kg})$ temporarily lost early in the experiment. Concentrates containing 13 to $14 \% \mathrm{CP}$ can be tentatively recommended as supplements to pastures of adequate quality, when fed to meet energy requirements of cows producing up to at least $20 \mathrm{~kg}$ of milk daily.
\end{abstract}

\section{RESUMEN}

Cuatro niveles de suplementación de proteina bruta para vacas pastando

Se compararon cuatro tratamientos $\left(T_{1}\right.$ al $\left.T_{4}\right)$, basados en concentrados aperdigonados con contenidos de proteína bruta $(C P)$, de 10.8, 12.2, 13.4 y $15.3 \%$, respectivamente tal como suplidos, pero teóricamente isocalóricos (1.67-1.70 Mcal, energía neta/kg), como suplementos al forraje pastorado. Las asignaciones de concentrados se basaron en la producción de leche, pero fijando un mínimo arbitrario de $4.5 \mathrm{~kg}$ diarios. La pacedura rotacional nocturna se efectuó en 12 predios de 0.5 ha de gramíneas heterogéneas,

'Manuscript submitted to Editorial Board 14 November 1989.

${ }^{2}$ Animal Nutritionist, Department of Animal Science and Lajas Substation, Agricultural Experiment Station, Mayagüez Campus, U.P.R. The author acknowledges the dedicated help of Santos Noel Caraballo in conducting this experiment. 
que recibieron poco abono y fluctuaron en calidad de adecuada a marginal en $11 \frac{1}{2}$ meses de experimentación.

Las vacas asignadas a los cuatro tratamientos produjeron, en el mismo orden, $21.3 \pm 3.0,22.5 \pm 4.4,20.3 \pm 2.5$ y $20.4 \pm 4.5 \mathrm{~kg}$ diarios de leche durante los 5 dias anteriores al inicio del experimento, y $14.4 \pm 1.2$, $16.8 \pm 3.9,15.2 \pm 2.4$ y $14.2 \pm 2.4 \mathrm{~kg}$. durante las 32 semanas experimentales. Aunque los promedios generales de producción no difírieron significativamente $(P>0.05)$, las vacas de $T_{1}$ disminuyeron su producción de $2.7 \mathrm{~kg}$ diarios durante el primer infervalo de 4 semanas $y$ hubo una menor persistencia en las de alfa producción; en $T_{2}$ también disminuyó la producción inicial, pero posteriormente la persistencia resultó ser superior. Los porcentajes de grasa láctea arrojaron una media de $2.78 \pm .49,2.68$ $\pm .44,2.88 \pm .33$ y $3.17 \pm .37$ en el $\mathrm{T}_{1}$ al $\mathrm{T}_{4}$. Su temprana disminución se debió, probablemente, al excesivo consumo de concentrado y al bajo consumo de fibra. El consumo de concentrado varió de $5.82 \mathrm{~kg}$ en $T_{4}$ a 7.10 $\mathrm{kg}$ en $\mathrm{T}_{2}$ durante 32 semanas; la razón de leche producida a concentrado consumido varió de 2.33 en $T_{3}$ a 2.45 en $T_{4}$. Sólo en la etapa inicial de $T_{1}$ hubo una apreciable pérdida temporera de peso vivo $(20 \mathrm{~kg})$. Se puede recomendar tentativamente el uso de concentrados con 13 a $14 \%$ de CP para suplementar animales que pastan forrajes de calidad adecuada si se les suministran las cantidades adecuadas para cubrir los requisitos de energía de vacas que producen diariamente hasta $20 \mathrm{~kg}$ de leche.

\section{INTRODUCTION}

The availability of concentrates of relatively low cost compared with high prices received for milk sold has resulted in heavy use of this convenient feed resource in nearly all the dairy herds of Puerto Rico (8). Efforts to induce dairy farmers to make greater use of high-quality pastures and reduce their dependency on imported concentrates have met with little success, in spite of experimental evidence demonstrating the feasibility of this alternative (17). Since this situation is likely to continue in the foreseeable future, research directed toward more efficient and less expensive formulation of concentrate feeds, adapted to local conditions, is well justified in economic terms.

Protein supplements are the most expensive macro-ingredients used in commercial concentrates. Controlled experiments to better define the protein levels genuinely needed to supplement grazing cows might save feed costs by adjusting protein contents downward. Previous shortterm experiments at the Lajas Substation have suggested the feasibility of such adjustments $(4,13)$. The present study was planned to test over a longer period concentrates of simple formulas and essentially constant theoretical net energy contents, but with 4 different levels of CP: one undoubtedly adequate (17.5\%, on the as fed basis), one expected to be suboptimal (10\%) and two evenly spaced intermediates (12.5 and 15\%). The objective was to determine the level above which additional CP in the concentrate produces no further improvement in animal performance.

\section{MATERIALS AND METHODS}

The experiment included 18 multiparous cows, 16 Holstein and 2 Brown Swiss, beginning not later than 8 weeks postpartum. The genital 
tracts of cows were examined by rectal palpation and those pronounced normal were incorporated into both the present study and another compatible experiment in which estrus synchronization was tested (3). A surgically modified heat detector bull was kept with the cows at pasture and while resting under shade during most of the first 9 months of observation, as required by the reproductive experiment.

Treatments compared in the feeding experiment consisted of supplementation with four different pelleted concentrate mixtures prepared in the mill facilities of the Lajas substation (table 1). These were formulated to be essentially isocaloric, on the basis of tabular values of NRC (12), and to increase in CP content by increments of approximately $2.5 \%$, from $10 \%$ to $17.5 \%$, in $\mathrm{T}_{1}$ through $\mathrm{T}_{4}$. Daily concentrate allowances were calculated at 4-week intervals according to the formula: (daily milk production $-5) \div 2$. However, a minimum allowance was arbitrarily set at $4.5 \mathrm{~kg}$ Thus the above formula became inoperative at daily productions below $14 \mathrm{~kg}$. This minimum supplementation was deemed necessary to maintain reasonable production in all cows, since adequate grazing conditions could not be guaranteed at all times.

The experiment was a complete randomized design with $5,4,5$ and 4 cows assigned to $T_{1}$ through $T_{4}$. The first 15 cows began the experiment from late November 1986 to mid February 1987; thereafter, the last 3 cows became available more slowly until the group was completed in early April 1987. All but one of the 18 cows were 5 to 8 weeks postpartum upon beginning the experiment. The lone exception (assigned to $\mathrm{T}_{3}$ ) was at an earlier stage of lactation. Each cow received her experimental concentrate feed for 32 weeks. Eleven received hormonal treatment for synchronization of estrus one or more times during the said period, including $4,2,3$ and 2 cows in $\mathrm{T}_{1}$ through $\mathrm{T}_{4}$ (3).

TABLE 1.-Percentage formulas, crude protein and net energy contentst of the four concentrates

\begin{tabular}{lcrrrr}
\hline & \multicolumn{4}{c}{ Treatment } \\
\cline { 2 - 5 } Ingredient or component (\%) & $\mathrm{T}_{1}$ & $\mathrm{~T}_{2}$ & $\mathrm{~T}_{3}$ & $\mathrm{~T}_{4}$ \\
\hline Ground maize & 65.5 & 60.5 & 55.4 & 50.3 \\
Wheat middlings & 23.0 & 21.2 & 19.5 & 17.7 \\
Soybean meal & 0 & 6.8 & 13.6 & 20.5 \\
Cane molasses & 10.0 & 10.0 & 10.0 & 10.0 \\
Salt & 1.0 & 1.0 & 1.0 & 1.0 \\
Dicalcium phosphate & 0.5 & 0.5 & 0.5 & 0.5 \\
Theoretical net energy (Mcal/kg) & 1.70 & 1.69 & 1.68 & 1.67 \\
Theoretical crude protein (\%) & 10.0 & 12.4 & 14.8 & 17.5 \\
Analyzed crude protein (\%) & 10.8 & 12.2 & 13.4 & 15.3 \\
\hline
\end{tabular}

Expressed as fed basis. 
Concentrates were fed individually while the cows were confined to stanchions in a shade barn, from about 10:30 am to $1 \mathrm{pm}$ daily. Concentrate refusals were recovered and small amounts (less than $0.5 \mathrm{~kg}$ ) were added to the next day's offering, whereas occasional larger quantities were subtracted from that offered to determine intake. During the remaining hours between the two daily milkings the animals rested in shaded areas nearby with only water available. Following milking at 2:30-3:00 pm they returned to pasture for approximately 13-14 hours until first milking of the following day.

A 6-ha pasture area, divided into 12 contiguous rectangular 0.5 -ha paddocks was grazed by 18 or 19 animals (3 or $3.167 /$ ha stocking rate) for a 24-day cycle. The lower numbers applied during the initial and final months of the experiment. When fewer than 17 or 18 experimental cows were participating, the balance of the animals needed to complete the group (excluding the lone male) were either the same cows before or after their 32 experimental weeks, or other lactating members of the herd.

Only paddock 1 (nearest the barn) supported a relatively pure stand of stargrass (Cynodon nlemfluensis), the others had mixed gramineous swards, with generally decreasing proportions of stargrass and increasing amounts of pajongrass (Andropongon annulatus), until the latter predominated in paddocks 9 through 12. Paragrass (Brachiaria mutica) was present in a low-lying strip of variable width that crossed the long axis of the pasture area. This strip received irrigation unintentionally because of leakage from nearby ditches, and tended to remain green during drought. Spot infestation with the gramineous weeds "cortadera" (Paspalum millegrana) and "matojo" (Sporobolus indicus) was common, but broadleaf weeds were a problem only in paddock 8 , where hand cutting was used sporadically to combat these weeds. The whole area was machine clipped once early in the experiment. These pastures had received only a light fertilization for several months before commencing this study and not until September 1987 was another $135 \mathrm{~kg}$ of 15-5-10 fertilizer applied to each paddock, by which time most of the cows had completed their 32 experimental weeks. Thus, conditions of little fertilization generally prevailed.

The experiment began with well rested pastures and abundant soil moisture, as $161 \mathrm{~mm}$ of rain fell in November 1986. Moderate precipitation of $33 \mathrm{~mm}$ in December, $62 \mathrm{~mm}$ in January and $60 \mathrm{~mm}$ during the first half of February was sufficient to maintain a good herbage supply. A dry spell lasted from mid February until mid May, during which time rainfall totaled only $50 \mathrm{~mm}$. By mid April an accumulative effect of the grazing pressure was evident in reduced height of the sward. Three times in late March and early April flood irrigation of the pastures was 
attempted, but with the ditches in an imperfect state of repair, water was distributed unequally. Abundant rains fell during the latter half of May $(116 \mathrm{~mm})$, but the corresponding increase in herbage availability lagged for some time. June was also favorable in rainfall $(158 \mathrm{~mm})$, but precipitation was suboptimal in July, August and early September (46 $\mathrm{mm}$ total) and herbage productivity declined once more. Finally, during the last 2 months of experimentation rain was plentiful $(306 \mathrm{~mm})$ and the sward recuperated. Clearly, gxazing conditions fluctuated greatly over the course of the experiment.

Beginning in January, when the 12th cow began the experiment, until September, pasture herbage was sampled 45 times. This process sought to provide quantitative estimates of vegetative material available. At each sampling, 24 hours or less before grazing, herbage in 5 widely dispersed and randomly selected $1 \mathrm{~m}^{2}$ plots per paddock was hand cut, weighed, and incorporated into a compositie sample to be oven dried at $60^{\circ} \mathrm{C}$ for dry matter (DM) determination. Six samples, one from each of the even numbered paddocks, taken in January and February, were analyzed for CP (14), ash (2), and fibrous fractions (7). Six samples of each of the four concentrates, accumulated over several weeks, were analyzed for CP content.

An aliquot of the milk from two consecutive milkings of each cow was obtained once per 4-week interval for determination of fat content by the Babock procedure (2). Every 4 weeks each cow was weighed once after morning milking. The data were submitted to a single factor analysis of variance (15).

\section{RESULTS AND DISCUSSION}

Analyzed CP contents of $T_{1}$ and $T_{2}$ concentrates agreed reasonably well with the theoretical values of $10 \%$ and $12.5 \%$ as fed, whereas those of $\mathrm{T}_{3}$ and $\mathrm{T}_{4}$ showed increasing discrepancies relative to the intended $15 \%$ and $17.5 \%$, respectively (table 1). Means and standard deviations of this variable on a DM basis were $12.1 \pm 0.7,13.6 \pm 0.3,15.0 \pm 1.2$, and $17.1 \pm 1.3 \%$ for $\mathrm{T}_{1}$ through $\mathrm{T}_{4}$ in that order. The use of different lots of ingredients and mixing these feeds on many different dates over nearly 12 months of experimentation were unavoidable disadvantages, which increased this variability. The assumption used as to CP content of soybean meal (48\% as fed) may have been too high during much of the experiment, and this would have progressively reduced the real CP contents of concentrates in $\mathrm{T}_{2}, \mathrm{~T}_{3}$ and $\mathrm{T}_{4}$ (but not in $\mathrm{T}_{1}$ ), according to the proportion of this ingredient in the formulas (table 1). Conversely, it was difficult to incorporate the full $10 \%$ of molasses in these mixtures, and inclusion of a lower level on some occasions increased analyzed $\mathrm{CP}$ values relative to the theoretical. Mean contents of chemical fractions observed 
in the pasture herbage $\mathrm{DM}$ were $\mathrm{CP}, 8.6 \pm 2.3$; ash, $11.3 \pm 1.2$; neutral detergent fiber, $75.0 \pm 2.6$; acid detergent fiber, $36.1 \pm 4.6$; hemicellulose, $39.0 \pm 3.4$; lignin, $6.6 \pm 0.9 \%$.

Mean milk production of all 18 cows during the 5 days immediately before commencing their participation in the experiment was $21.1 \mathrm{~kg}$ daily (table 2). The groups destined to $\mathrm{T}_{3}$ and $\mathrm{T}_{4}$ had similar means that were inferior to those of $\mathrm{T}_{1}$ and $\mathrm{T}_{2}$ cows by approximately 1 and $2.2 \mathrm{~kg}$, respectively. Within-group variability was less for $T_{1}$ and $T_{3}$ than for $T_{2}$ and $\mathrm{T}_{4}$. Regression coefficients relating daily milk production during the experiment to the same variable during the 5-day preliminary period differed markedly among treatments, from $0.32 \mathrm{~kg}$ for $\mathrm{T}_{1}$ to $0.92 \mathrm{~kg}$ for $\mathrm{T}_{3} . \mathrm{T}_{2}$ also gave a high coefficient $(0.88 \mathrm{~kg})$, whereas that of $\mathrm{T}_{4}$ was surprisingly low $(0.51 \mathrm{~kg})$. These regressions indicate that cows of higher initial milk yield maintained their advantage better in $\mathrm{T}_{2}$ and $\mathrm{T}_{3}$ than in $\mathrm{T}_{1}$ and $\mathrm{T}_{4}$. Since the variability among individual treatment regressions was significant $(\mathrm{P}<.05)$, use of a common regression was rendered null and the possibility of submitting the milk production data to the corresponding covariance analysis was precluded (15).

Milk production during 32 weeks of experimentation was highest in $\mathrm{T}_{2}$ and lowest in $\mathrm{T}_{4}$, similar to preliminary period standings; $\mathrm{T}_{3}$ improved its relative position, whereas $T_{1}$ declined in mean standing and also in within-group variability (table 2 ). This tendency was also evident in $\mathrm{T}_{4}$. Treatments did not constitute a significant source of variance in milk yield $(\mathrm{P}>.05)$. The ratio of experimental period production/preliminary period production, used as an index of lactational persistency, gave the mean result 0.75 for both $T_{2}$ and $T_{3}$, compared with lower values of 0.68 and 0.70 for $\mathrm{T}_{1}$ and $\mathrm{T}_{4}$, respectively (table 2 ).

The low-protein concentrate fed in $\mathrm{T}_{1}$ was expected to adversely affect lactation, but there is no evident explanation for the negative effect of $\mathrm{T}_{4}$. The poor results obtained with the cows in $\mathrm{T}_{4}$ can probably be

TABLE 2.-Mean daily milk production during the preliminary and experinental periods, index of lactational persisteney and milk fat content.

\begin{tabular}{|c|c|c|c|c|}
\hline \multirow[b]{2}{*}{ Treatment } & \multicolumn{3}{|c|}{ Milk production } & \multirow{2}{*}{$\begin{array}{c}\text { Experimental } \\
\text { period } \\
\text { milk fat }\end{array}$} \\
\hline & Preliminary & Experimental & Persistency ${ }^{1}$ & \\
\hline & $\mathrm{kg}$ & $\mathrm{kg}$ & & $\%$ \\
\hline$T_{1}$ & $21.32 \pm 2.99^{2}$ & $14.43 \pm 1.20$ & 0.68 & $2.78 \pm 0.49$ \\
\hline $\mathrm{T}_{2}$ & $22.53 \pm 4.42$ & $16.81 \pm 3.91$ & 0.75 & $2.68 \pm 0.44$ \\
\hline $\mathrm{T}_{3}$ & $20.33 \pm 2.48$ & $15.17 \pm 2.36$ & 0.75 & $2.88 \pm 0.33$ \\
\hline $\mathrm{T}_{4}$ & $20.37 \pm 4.54$ & $14.25 \pm 2.44$ & 0.70 & $3.17 \pm 0.37$ \\
\hline Total & $21.10 \pm 3.38$ & $15.12 \pm 2.53$ & 0.72 & $2.87 \pm 0.41$ \\
\hline
\end{tabular}

' Ratio of experimental period to preliminary period milk production.

¿Standard deviation. 
ascribed to random effects of assignment of cows to treatments. With only 4 animals in $\mathrm{T}_{4}$ random differences could easily have been important. A comparison of milk production in $T_{1}$ vs $T_{2}, T_{3}$ and $T_{4}$ combined gives respective means of 14.43 and $15.41 \mathrm{~kg}$ daily. This $0.98-\mathrm{kg}$ difference represents a reduction in milk production of $6.4 \%$ ascribable to restricted protein intake in $T_{1}$, although the statistical validity of this effect was not established by the present limited data. If results with $\mathrm{T}_{4}$ are excluded as possibly atypical, the comparison of $\mathrm{T}_{1}$ vs $\mathrm{T}_{2}$ and $\mathrm{T}_{3}$ shows mean daily productions of 14.43 and $15.99 \mathrm{~kg}$, representing a difference of $1.56 \mathrm{~kg}$ or $9.8 \%$. By either estimate no more than $10 \%$ of expected production was lost because of protein restriction.

Milk production data during successive 4-week intervals of experimentation (table 3 ) show that the adverse effect of $\mathrm{T}_{1}$ was limited mostly to the first 4 weeks. Mean production by $\mathrm{T}_{1}$ cows of $18.60 \mathrm{~kg}$ during this interval was $2.72 \mathrm{~kg}$ below that of the 5-day preliminary period. Thereafter milk yield in $\mathrm{T}_{1}$ declined to $10.05 \mathrm{~kg}$ daily during the final 4 weeks, a total reduction of $8.55 \mathrm{~kg}$ in 7 successive steps or 1.22 $\mathrm{kg}$ per 4-week interval. Cows of $\mathrm{T}_{2}, \mathrm{~T}_{3}$ and $\mathrm{T}_{4}$ produced respectively $2.19,0.36$ and $1.24 \mathrm{~kg}$ less during the first 4 weeks than during the

TABLE 3.-Daily milk production and concentrate intake during successive 4-week intervals, milk fat content and liveweight determined once per interval

\begin{tabular}{|c|c|c|c|c|c|c|c|c|}
\hline \multirow{2}{*}{$\begin{array}{l}\text { Weeks of } \\
\text { experiment }\end{array}$} & \multicolumn{4}{|c|}{ Treatment } & \multicolumn{4}{|c|}{ Treatment } \\
\hline & $\mathrm{T}_{1}$ & $\mathrm{~T}_{2}$ & $\mathrm{~T}_{3}$ & $\mathrm{~T}_{4}$ & $\mathrm{~T}_{1}$ & $T_{2}$ & $\mathrm{~T}_{3}$ & $\mathrm{~T}_{4}$ \\
\hline & \multicolumn{4}{|c|}{ Wilk production (kg) } & \multicolumn{4}{|c|}{ Liveweight $(\mathrm{kg})$} \\
\hline $0^{1}$ & 21.3 & 22.5 & 20.3 & 20.4 & 560 & 523 & 545 & 544 \\
\hline 4 & 18.6 & 20.3 & 20.0 & 19.1 & 549 & 519 & 541 & 553 \\
\hline 8 & 17.4 & 18.4 & 18.5 & 17.5 & 549 & 532 & 538 & 549 \\
\hline 12 & 16.6 & 18.4 & 16.8 & 16.0 & 540 & 526 & 547 & 551 \\
\hline 16 & 15.2 & 17.2 & 15.8 & 14.2 & 549 & 523 & 552 & 544 \\
\hline 20 & 14.1 & 16.3 & 14.4 & 13.5 & 550 & 516 & 553 & 554 \\
\hline 24 & 12.1 & 16.0 & 13.6 & 12.7 & 564 & 548 & 552 & 562 \\
\hline 28 & 11.3 & 14.8 & 11.7 & 11.4 & 565 & 553 & 566 & 572 \\
\hline \multirow[t]{2}{*}{32} & 10.0 & 13.0 & 10.6 & 9.6 & 568 & 563 & 574 & 579 \\
\hline & \multicolumn{4}{|c|}{ Concentrate intake $(\mathrm{kg})$} & \multicolumn{4}{|c|}{ Milk fot $(\%)$} \\
\hline 4 & 8.05 & 8.57 & 8.34 & 7.65 & 2.68 & 2.08 & 2.46 & 2.66 \\
\hline 8 & 7.58 & 8.43 & 8.10 & 7.24 & 2.03 & 2.06 & 2.50 & 2.94 \\
\hline 12 & 6.86 & 8.02 & 7.22 & 6.68 & 2.67 & 2.30 & 2.40 & 2.95 \\
\hline 16 & 6.30 & 7.51 & 6.68 & 5.76 & 2.59 & 2.52 & 2.70 & 3.15 \\
\hline 20 & 5.84 & 6.84 & 6.01 & 5.30 & 2.99 & 2.78 & 3.06 & 3.38 \\
\hline 24 & 4.96 & 6.15 & 5.80 & 4.70 & 3.12 & 3.04 & 3.29 & 3.55 \\
\hline 28 & 4.54 & 5.74 & 5.17 & 4.70 & 3.42 & 3.10 & 3.50 & 3.70 \\
\hline 32 & 4.50 & 5.52 & 4.68 & 4.52 & 3.42 & 2.98 & 3.93 & 3.67 \\
\hline
\end{tabular}

Preliminary period of 5 days. 
preliminary period. Thus, $\mathrm{T}_{2}$ also had an appreciable negative effect upon first exposure of the animals. However, during the remaining 28 weeks the cows in this treatment compensated for the previous decline with greater persistency, losing $1.05 \mathrm{~kg}$ per 4 -week interval, compared with 1.34 and $1.36 \mathrm{~kg}$ in $\mathrm{T}_{3}$ and $\mathrm{T}_{4}$, respectively.

Before the experiment these animals had been receiving the regular herd concentrate with at least $16 \% \mathrm{CP}$ in the DM. Two factors may have contributed to adverse effects of the lower protein concentrates of $\mathrm{T}_{1}$ during the first 4-week interval: first, protein restriction had a greater impact at higher levels of production; second, gradual adjustment to the lower protein rations was needed. Ruminant animals can save scarce dietary nitrogen, once adjusted to low intakes, especially if digestible energy is not limiting, by several physiological adjustments, including recycling urea back to the rumen for microbial protein synthesis (16). Earlier introduction of the lower protein concentrates might have permitted such adjustments before peak production, but this is a matter of speculation. Observations beginning in earliest lactation or even before parturition, would shed light on this question.

In a Cuban study, Holstein cows in early lactation grazing coastcross bermudagrass (Cynodon dactylon) at a stocking rate of 3.5/ha and supplemented with $6 \mathrm{~kg}$ of concentrates daily, produced significantly more milk (16.9 vs $16.3 \mathrm{~kg}$ daily) when the supplement contained $18 \%$ rather than $16 \% \mathrm{CP}(5)$. However, the former was also higher in metabolizable energy (13.3 vs $11.6 \mathrm{MJ} / \mathrm{kg} \mathrm{DM}$ ). Thus the specific effect of protein level could not be ascertained. At any rate, the relative difference in production between treatments was only $4 \%$.

Table 4 presents theoretical calculations of $\mathrm{CP}$ required and $\mathrm{CP}$ consumed by cows in the four treatments under the mean conditions of this experiment. A liveweight ( $\mathrm{LW}$ ) of $550 \mathrm{~kg}$ was used in accounting for maintenance needs, and protein required per unit of milk produced was

TABLE 4.-Theoretical estimates of daily dry matter intake from pasture herbage required to satisfy that part of the crude protein requirement not supplied by concentrates

\begin{tabular}{|c|c|c|c|c|c|c|c|}
\hline \multirow[b]{2}{*}{ Treatment } & \multicolumn{3}{|c|}{ Crude protein requirement ${ }^{\prime}$} & \multicolumn{2}{|c|}{ Crude protein intake } & \multicolumn{2}{|c|}{ Herbage DM intake" } \\
\hline & $\begin{array}{l}\text { Mainte- } \\
\text { nance }\end{array}$ & $\begin{array}{l}\text { Milk pro- } \\
\text { duction }\end{array}$ & Total & $\begin{array}{l}\text { From con- } \\
\text { centrate }\end{array}$ & $\begin{array}{l}\text { From } \\
\text { pasture }\end{array}$ & Total & $\begin{array}{l}\text { Relative } \\
\text { to live- } \\
\text { weight }\end{array}$ \\
\hline & $g$ & $g$ & $g$ & $g$ & $g$ & $\mathrm{~kg}$ & $\%$ \\
\hline $\mathrm{T}_{1}$ & 461 & 1082 & 1543 & 657 & 886 & 10.30 & 1.87 \\
\hline $\mathrm{T}_{2}$ & 461 & 1244 & 1705 & 866 & 839 & 9.76 & 1.77 \\
\hline$T_{3}$ & 461 & 1153 & 1614 & 871 & 743 & 8.64 & 1.57 \\
\hline $\mathrm{T}_{4}$ & 461 & 1126 & 1587 & 890 & 697 & 8.10 & 1.47 \\
\hline
\end{tabular}

'According to NRC (12).

${ }^{2}$ Assuming $8.6 \%$ crude protein in the dry matter. 
assumed to vary with milk fat percentage (12). The mean of $8.6 \% \mathrm{CP}$ found in the pasture herbage agrees with past experience $(1,4)$. This figure, which applies to the total DM on offer, was used with no attempt to take selective grazing into account. The capacity to consume forage would logically have increased with time as intake of concentrates declined; however, averaging over-all, cows in $\mathrm{T}_{1}$ would have had to ingest $10.3 \mathrm{~kg}$ of herbage DM daily, equivalent to $1.87 \%$ of $\mathrm{LW}$, to obtain the necessary $886 \mathrm{~g}$ of CP not supplied by the concentrate. This estimate is reasonable for a ration also including $6.08 \mathrm{~kg}$ of concentrate (table 5), equivalent to $5.43 \mathrm{~kg}$ of DM (approximately $1 \%$ of LW daily) (6). Estimated pasture herbage intakes required to complete the CP requirements of cows in $\mathrm{T}_{2}, \mathrm{~T}_{3}$ and $\mathrm{T}_{4}$ are progressively lower (table 4). Thus, all of these rations should have supplied adequate CP over-all. A deficiency is postulated for $T_{1}$ and less so for $T_{2}$ only during the early weeks of experimentation.

Based on 43 of 45 pasture samplings (data from 2 partially lost), mean availability of green herbage per 0.5 ha paddock was 2.46 metric tons and herbage DM content $35.2 \%$. The latter figure indicates the presence of much dead vegetative matter in lower strata of the sward. Based on 36 or 38 animal-days per paddock per grazing over the experiment, herbage DM available was estimated as $22 \pm 11 \mathrm{~kg}$ per animal-day. This high variability (C.V. 50\%) is not surprising. Individual samplings based on only 5 sub-samples per 0.5 -ha paddock of heterogeneous herbage are not very reliable, but the pooled data permit following the general trend with time and provide a mean estimate of herbage DM available equivalent to $4 \mathrm{~kg}$ per $100 \mathrm{~kg}$ of LW daily. Accordingly, the animals could consume DM at the rate of $2 \%$ of LW by ingesting half of the herbage on offer. This would permit selective grazing. Variations over seasons and among different paddocks were undoubtedly important, but these could not be quantified from the limited data available. However, the trends observed toward less height of the sward and lower DM availability with time indicate that the grazing pressure used was not sustainable under these conditions of little fertilization and periodically inadequate soil moisture.

TABLE 5.-Mean daily intake of concentrates, ratio of milk produced to concentrate consumed and mean liveweight

\begin{tabular}{lccc}
\hline Treatment & Concentrate intake & Milk/concentrate & Liveweight \\
\hline & $k g$ & & $k g$ \\
$\mathrm{~T}_{1}$ & 6.08 & 2.37 & 554 \\
$\mathrm{~T}_{2}$ & 7.10 & 2.37 & 535 \\
$\mathrm{~T}_{3}$ & 6.50 & 2.33 & 553 \\
$\mathrm{~T}_{4}$ & 5.82 & 2.45 & 558 \\
\multicolumn{1}{r}{ Total } & 6.38 & 2.38 & 550 \\
\hline
\end{tabular}


Mean milk fat content over 32 weeks was below the legal minimum of $3 \%$ in all except $\mathrm{T}_{4}$ (table 2). Depressed milk fat was observed early in the experiment in most of the cows, but this condition improved with advancing lactation as milk production declined (table 3). An inverse relationship between milk yield and milk fat percentage is normal (11). Also, with time forage intake should have increased in absolute terms and the ratio of forage to concentrate consumed certainly became wider. Protein intake may have been an additional factor. Investigators in North Carolina (9) compared concentrates containing 13 vs $23 \%$ CP in conjunction with widely different concentrate: forage ratios, using alfalfa-grass mixed hay, and found a significant effect of the high-protein concentrate in mitigating milk fat depression when the diet was low in fiber, especially in primiparous cows, whereas little effect was seen with the highfiber diet. A subsequent similar study (10) confirmed the effect of a high-protein concentrate, fed with a low proportion of hay, on milk fat content, but also showed that a high level of body condition in early lactation tend, to counteract this effect. In the present study, with a more lir . $\mathrm{d}$ range of $\mathrm{CP}$ percentages in the concentrates, treatments did not ignificantly affect milk fat; the same general trend was noted, however, toward increased milk fat with higher concentrate CP, especially during the early stages (table 3 ). Possibly, the quantity of protein supplied by concentrates affected consumption and/or digestibility of the pasture herbage.

The vast majority of all concentrate offerings were consumed; thus mean intakes per treatment varied directly with milk production (tables 2 and 5). The ratio of milk produced to concentrate consumed (partial feed efficiency) varied little among treatments, highest in $\mathrm{T}_{4}$ and lowest in $\mathrm{T}_{3}$ (table 5). Variability in feed conversion efficiency was mostly a function of the method of allotting concentrates rather than an effect of the treatments. At any rate, the over-all ratio of 2.38 represents better efficiency in the use of concentrates than usually prevails on local commercial dairy farms (8).

Mean LW over the experiment was nearly alike in $\mathrm{T}_{1}, \mathrm{~T}_{3}$ and $\mathrm{T}_{4}$, whereas $\mathrm{T}_{2}$ cows were about $20 \mathrm{~kg}$ lighter (table 5 ). Only in $\mathrm{T}_{1}$, was any appreciable LW loss recorded during the early stages $(20 \mathrm{~kg})$, but this had been recovered by the 24 th experimental week (table 3 ). Cows of $\mathrm{T}_{2}$, $\mathrm{T}_{3}$ and $\mathrm{T}_{4}$ showed over-all $\mathrm{LW}$ increments of 40,29 and $35 \mathrm{~kg}$, respectively, vs only $8 \mathrm{~kg}$ for $\mathrm{T}_{1}$. This difference might be another reflection of protein supply.

Cows of $\mathrm{T}_{2}$ and $\mathrm{T}_{3}$ were free of clinical mastitis during the experiment; two cows of $\mathrm{T}_{1}$ were affected briefly and one cow of $\mathrm{T}_{4}$ was affected on two separate occasions. Two abortions occurred, one each in $\mathrm{T}_{1}$ and $\mathrm{T}_{3}$, but the cows in question were rebred and all 18 animals had a subsequent calving in the herd, following mean intervals of $464,438,430$, and 438 
days in $\mathrm{T}_{1}$ through $\mathrm{T}_{4}$. The mean number of inseminations required to achieve subsequent calving was $3.6,3.0,2.8$ and 3.25 , respectively. Three $\mathrm{T}_{4}$ cows conceived at first service and had calving intervals of less than 365 days, but the 4 th member of this group was a very slow breeder (718-day calving interval and 10 inseminations required) and markedly affected the treatment means. These data provide a slight indication that protein restriction in $T_{1}$ could have adversely affected reproductive efficiency (possibly as a result of the transient loss of body condition), but these limited data do not permit a meaningful assessment of this relationship.

The present results need confirmation, but if upheld by further experimentation they could have important practical implications. Under conditions of liberal (not extreme) concentrate supplementation for cows averaging $21 \mathrm{~kg}$ of milk per day initially and grazing generally adequate but sometimes marginal swards, the 10.8 and $12.2 \%$ CP (as fed) concentrates of $\mathrm{T}_{1}$ and $\mathrm{T}_{2}$ showed signs of adversely affecting lactational performances only during the early weeks when production was highest, relative to the results obtained with 13.4 and $15.3 \% \mathrm{CP}$ concentrates of $\mathrm{T}_{3}$ and $\mathrm{T}_{4}$. In a previous study of similar procedure but shorter duration, liberally fed $13 \%$ CP concentrates (either bulky or of conventional type) appeared adequate as supplements for grazing cows of similar productive capacity but of later initial stage of lactation, relative to the present case, although concentrates of different CP percentages were not included for comparison (13).

Since most dairy farmers in Puerto Rico feed concentrates containing at least $16 \%$ and often $18 \% \mathrm{CP}$, even for cows grazing pastures better than those of the present experiment, it can be tentatively concluded that over-feeding of protein is a common practice. A saving in feed costs could be realized by using concentrates with lower CP contents, when grazing conditions are reasonably favorable and sufficient concentrate is fed to meet energy requirements. It should be stressed that this conclusion applies specifically to grazing situations and should not be extrapolated to rations based on harvested forages without verification by controlled experimentation.

\section{LITERATURE CITED}

1. Almeyda-Domenech, C. and P. F. Randel, 1989. Two levels of liquid Streptomyces solubles in pelleted concentrate feeds for dairy cows. J. Agric. Univ. P. R. 73: 1-9.

2. AOAC, 1980. Official Methods of Analysis. 13th ed. Association of Official Analytical Chemists. Washington, D.C.

3. Cubero-Valderrama, D. E., 1988. La utilización de la prostaglandina F2 (Lutalyse ${ }^{R}$ ) como ayuda en el manejo reproductivo posparto de vacas lecheras. M.S. Thesis. U. P. R., Mayagüez Campus.

4. Delgado, I. and P. R. Randel, 1989. Supplementation of cows grazing tropical grass swards with concentrates varying in protein level and degradability. J. Dairy Sci. 72: $995-1001$. 
5. García-López, R., O. Martínez, P. Ponce y M. Menchaca, 1988. Evaluación de dos concentraciones energéticas-proteicas al inicio de la lactancia en vacas Holstein en pastoreo. Rev. Cubana Cienc. Agric. 22: 135-8.

6. Garcia-Trujillo, R. y O. Cáceres, 1985. Introducción de nuevos sistemas para expresar el valor nutritivo de los forrajes tropicales. IV Consumo. Pastos y Forrajes (Rev. de E.E.P.F. "Indio Hatuey") 8: 449-70.

7. Goering, H. F. and P. J. van Soest, 1970. Forage fiber analysis (apparatus, reagents, procedures and some applications). USDA Agric. Handb. 379.

8. González, J., 1989. Situación de la empresa de ganadería lechera de Puerto Rico. Dep. Agric. Econ. U. P. R., Mayagüez Campus.

9. Jaquette, R. D., A. H. Rakes and W. J. Groom, Jr., 1986. Effects of dietary protein on milk, rumen, and blood parameters in dairy cows fed low fiber diets. J. Dairy Sci. 69: 1026-34.

10. —, - - - - 1988. Effects of body condition and protein on milk fat depression in early lactation cows. J. Dairy Sci. 71: 2123-34.

11. McDonald, P., R. A. Edwards and J. F. D. Greenhalgh, 1966. Animal Nutrition. 2nd. ed., Longmans, Inc., New York.

12. National Research Council, 1978. Nutrient Requirements of Domestic Animals. No. 3. Nutrient Requirements of Dairy Cattle. 5th. ed., National Academy of Sciences, Washington, D.C.

13. Rodriguez, Y. y P. F. Randel, 1988. Concentrados voluminosos y proteína protegida para vacas lecheras. XI Mtg. ALPA. Havana. April, 1988.

14. Scales, F. M. and H. E. Harrison, 1920. Boric acid modification of the Kjeldahl method for crop and soil analysis. J. Ind. Eng. Chem. 12: 350-52.

15. Snedecor, G. W., 1956. Statistical Methods. 5th. ed., The Iowa State College Press, Ames, Iowa.

16. Van Soest, P. J., 1982. Nutritional Ecology of the Ruminant. O \& B Books, Inc., Corvallis, Oregon.

17. Yazman, J. A., R. E. McDowell, H. Cestero, J. A. Arroyo-Aguilú, J. D. Rivera-Anaya, M. Soldevila and F. Román-García, 1982. Efficiency of utilization of tropical grass pastures by lactating cows with and without supplement. J. Agric. Univ. P. R. 66: 200-22. 